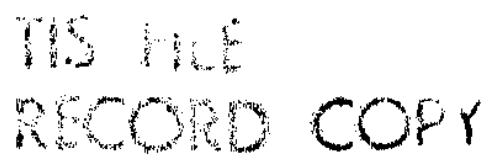

\title{
EFFECT OF INTERNAL ALPHA RADIATION ON BOROSILICATE GLASS CONTAINING SAVANNAH RIVER PLANT WASTE
}

N. E. BIBLER and J. A. KELLEY

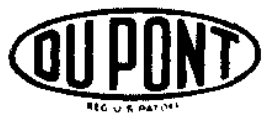

SAVANNAH RIVER LABORATORY AIKEN, SOUTH CAROLINA 29801 


\section{NOTICE}

This report was prepared as an account of work sponsored by the United States Government. Neither the United States nor the United States Department of Energy, nor any of their contractors, subcontractors, or their employees, makes any warranty, express or implied or assumes any legal liability or responsibility for the accuracy, completeness or usefulness of any information, apparatus, product or process disclosed, or represents that its use would not infringe privately owned rights.

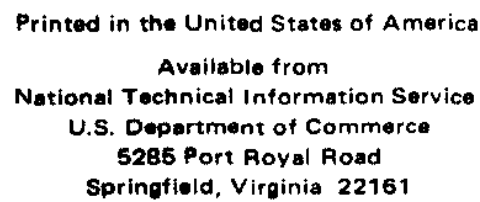

Price: Printed Copy $\$ 4.00$; Microfiche $\$ 3.00$ 


\section{EFFECT OF INTERNAL ALPHA RADIATION ON BOROSILICATE GLASS CONTAINING SAVANNAH RIVER PLANT WASTE}

by

N. E. BIBLER and J. A. KELLEY

Approved by

M. L. Hyder, Research Manager

Separations Chemistry Division

Publication Date: May 1978

E. I. DU PONT de NEMOURS aNo COMPANY SAVANNAH RIVER LABORATORY AIKEN, SOUTH CAROLINA 29801 


\section{ABSTRACT}

Effects of internal alpha radiation on borosilicate glass, a perspective matrix for long-term storage of Savannah River Plant (SRP) radioactive waste, were evaluated in samples containing $45 \mathrm{wt}$ $\%$ simulated waste $\left[\mathrm{Fe}(\mathrm{OH})_{3}-\mathrm{MnO}_{2}\right]$ and either 0.5 wt $\%{ }^{244} \mathrm{Cm}$ or 1 wt $\%$ ${ }^{23}{ }^{8} \mathrm{Pu}$. A glass containing ${ }^{238} \mathrm{Pu}$ without simulated waste was also studied for comparison. The glasses were examined for changes in physical stability, leachability, and dilatation.

Alpha dose rates in the test glasses ranged from $4.5 \times 10^{14}$ to $1.3 \times 10^{15}$ alpha dis/(g-day). After 420 days, microcracks had formed; however, no macrostructural damage to the glasses was observed. Leachabilities for ${ }^{244} \mathrm{Cm}$ and ${ }^{238} \mathrm{Pu}$ were $<7 \times 10^{-8}$ $\mathrm{g} /\left(\mathrm{cm}^{2}\right.$-day) and were not affected by the radiation. Continuous leaching by water for 5 days removed $<10^{-5} \frac{\mathrm{o}}{6}$ of the isotopes. Alpha radiolysis caused expansion of the simulated-waste glasses in proportion to dose. Application of these results to glass containing radioactive Savannah River Plant waste indicated that internal alpha radiolysis will not cause detrimental effects during long-term storage $\left(>10^{6}\right.$ years) of the waste glass. 


Introduction 5
Calculated Alpha Doses to Glass Containing SRP Waste 5
Test Glasses Containing ${ }^{244} \mathrm{Cm}$ or ${ }^{238} \mathrm{Pu}$ and Simulated Waste 7
Effect of Alpha Radiation on Actinide Leachability 8
Effect of Alpha Radiation on Glass Volume 10
Effect of Alpha Radiation on Glass Microstructure 11
Helium Accumulation in the Glass 13
Stored Energy Resulting from Alpha Radiation 14
References 15




\section{LIST OF TABLES}

1 Properties of Three Test Glasses Containing ${ }^{244} \mathrm{Cm}$ or ${ }^{238} \mathrm{Pu} \quad 8$

2 Leachability of ${ }^{244} \mathrm{Cm}$ or ${ }^{238} \mathrm{Pu}$ from Borosilicate Glasses Containing Simulated Radioactive Waste 9

\section{LIST OF FIGURES}

1 Cumulative Alpha Dose to Glass Containing Radioactive SRP Waste 6

2 Positive Dilation Due to Internal Alpha Radiolysis of Borosilicate Glasses Containing ${ }^{244} \mathrm{Cm}$ or ${ }^{238} \mathrm{Pu} \quad 10$

3 Electron Microscope Images of Borosilicate Glasses Containing Simulated Radioactive Wastes 12

4 B1ister Formation on a Borosilicate Glass Containing ${ }^{238} \mathrm{Pu}$ Due to Exposure to a Beam in an Electron Microscope 13 


\section{INTRODUCTION}

Borosilicate glass is currently being evaluated ${ }^{1,2}$ as a long-term storage matrix for radioactive waste generated at the Savannah River Plant (SRP). For incorporation in glass, this waste will be a dry mixture of hydrous oxides primarily of iron, manganese, and aluminum contaminated with fission products, uranium, and transuranic elements. ${ }^{3}$ The glass has properties of high strength and low leachability that make it an attractive solidification matrix.

Processes in which glass will be used for solidifying radioactive waste have been in operation 4,5 or are currently being tested at other sites. ${ }^{6,7}$ Also, studies ${ }^{8-10}$ of the effects of internal alpha radiation on glasses containing simulated waste have been performed. These studies have examined the effects of alpha radiation on leachability, stored energy, and density changes of the glass. However, these processes and studies are not directly applicable to solidification of SRP waste because the composition of the waste differed from that at SRP.

This report presents results of the evaluation of the effects of internal alpha radiation on a borosilicate glass developed especially for solidifying SRP radioactive waste. ${ }^{1,2}$ To accelerate the effects of alpha damage that will occur during long-term storage of the glass, relatively large amounts of the alpha emitters ${ }^{244} \mathrm{Cm}$ or ${ }^{238} \mathrm{Pu}$ were incorporated in test glasses. The alpha emitters increased the alpha dose rate so that the alpha dose that would be accumulated in SRP waste glass during several thousand years storage could be obtained in the test glasses in a few months.

\section{CALCULATED ALPHA DOSES TO GLASS CONTAINING SRP WASTE}

The alpha dose received by glass containing SRP waste depends upon the radionuclide content of the waste. Principle alpha emitters in this waste are ${ }^{244} \mathrm{Cm}\left(\mathrm{t} \frac{1}{2}=18\right.$ years $),{ }^{2{ }^{8}} \mathrm{Pu}$ $\left(t \frac{1}{2}=88\right.$ years), and ${ }^{239} \mathrm{Pu}\left(t \frac{1}{2}=2.4 \times 10^{4}\right.$ years $)$. Approximately $1 \times 10^{5} \mathrm{Ci}$ of ${ }^{244} \mathrm{Cm}, 2 \times 10^{5} \mathrm{Ci}$ of ${ }^{238} \mathrm{Pu}$, and $2 \times 10^{4} \mathrm{Ci}$ of ${ }^{239} \mathrm{Pu}$ will be solidified. ${ }^{3}$ To calculate the alpha dose, the assumed total mass of solidified waste glass was $2 \times 10^{7} \mathrm{~kg}$. With this alpha content, the initial dose rate was $7 \times 10^{18}$ dis/(g-day). The accumulated dose to the glass from decay of the ${ }^{24{ }^{4}} \mathrm{Cm},{ }^{238} \mathrm{Pu}$, and ${ }^{239} \mathrm{Pu}$ is shown in Figure 1 . 


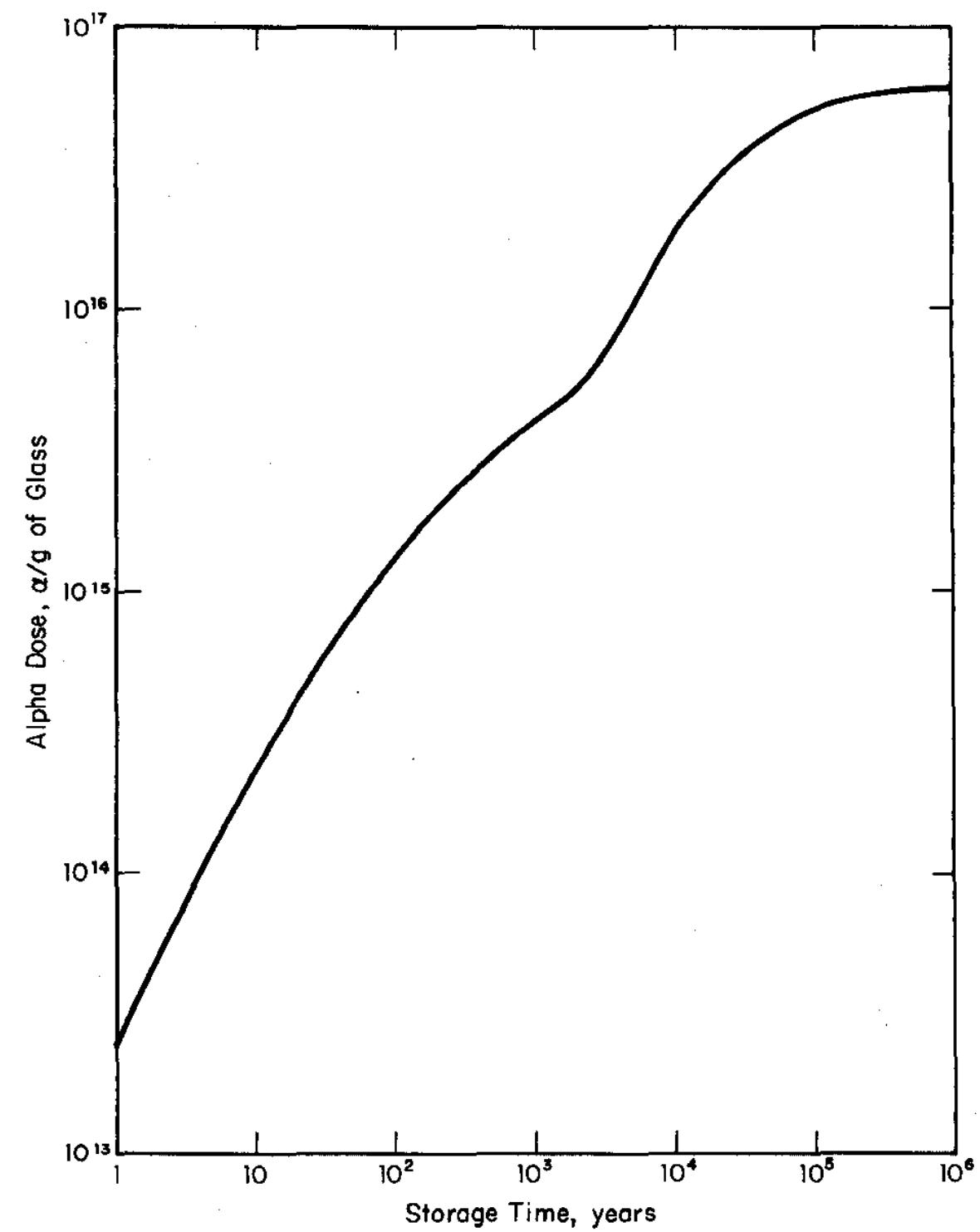

FIGURE 1. Cumulative Alpha Dose to Glass Containing Radioactive SRP Waste 
The total dose was calculated by adding the doses from decay of each isotope. The dose from each isotope was calculated from the equation.

$$
D_{t}=\frac{I_{O}}{\lambda}\left(1-e^{-\lambda t}\right)
$$

where

$$
\begin{aligned}
& D_{t}=\text { dose at time } t \text { from a specific isotope, } \alpha / g \text { glass } \\
& I_{0}=\text { initial dose rate for that isotope, } \alpha /(g-y r) \\
& \lambda=\text { decay constant for that isotope, (year })^{-1} \\
& t=\text { decay times in years }
\end{aligned}
$$

The inflection in the curve at $10^{3}$ years occurs when ${ }^{244} \mathrm{Cm}$ and ${ }^{238} \mathrm{Pu}$ have decayed, and the dose from decay of ${ }^{239} \mathrm{Pu}$ has not yet become significant.

\section{TEST GLASSES CONTAINING ${ }^{244} \mathrm{Cm}$ OR ${ }^{238} \mathrm{Pu}$ AND SIMULATED WASTE}

Oxide composition (by wt \%) of the glass-forming mixture for the glasses test was $52.5 \% \mathrm{SiO}_{2}, 10 \% \mathrm{~B}_{2} \mathrm{O}_{3}, 22.5 \% \mathrm{Na}_{2} \mathrm{O}$, $10 \% \mathrm{TiO}_{2}$, and $5 \% \mathrm{CaO}$. Previous experiments ${ }^{1}$ have shown that this glass composition is acceptable for incorporation of solid SRP radioactive waste. ${ }^{2}$ Simulated dry waste $\left[50 \mathrm{~mol} \% \mathrm{Fe}(\mathrm{OH})_{3}\right.$ and $50 \mathrm{~mol} \% \mathrm{MnO}_{2}$ ] was added to portions of glass-forming mixture for two of the samples to the level of 45 wt $\%$ waste. ${ }^{244} \mathrm{Cm}$ was added to one waste-oxide mixture and ${ }^{238} \mathrm{Pu}$ to the other. These isotopes were added as small volumes of nitrate solutions and were thoroughly dispersed in the respective mixes. Another glass containing ${ }^{3{ }^{8}} \mathrm{Pu}$, but no simulated waste, was also made. The final mixes were slowly heated to $1150^{\circ} \mathrm{C}$ in ceramic crucibles and held at that temperature for 3 hours. The melts were poured into graphite molds, annealed at $500^{\circ} \mathrm{C}$ for 1 hour, and then cooled slowly. The glasses were then stored at ambient temperatures and relative humidity $(260 \%)$.

Initial densities and other properties of the three test glasses are shown in Table 1. The glasses were shiny, opaque, and brownish-blue in color. Glasses containing simulated waste had much larger densities than normal glass because oxides of iron or manganese fill vacancies in the glass network. 
TABLE 1

Properties of Three Test Glasses Containing ${ }^{244} \mathrm{Cm}$ or ${ }^{238} \mathrm{Pu}$

$\begin{array}{llll}\text { Glass Mass, g } & 16.4 & 14.5 & 7.93 \\ \text { Isotope Present } & { }^{244} \mathrm{Cm} & 238 \mathrm{Pu} & 238 \mathrm{Pu} \\ \text { Wt } \% \text { Simulated Waste } & 45 & 45 & 0 \\ \text { Wt } \%{ }^{24} \mathrm{Cm} \text { or }{ }^{238} \mathrm{Pu} & 0.49 & 0.97 & 0.81 \\ \text { Density, g/cm }{ }^{3} & 3.0474 & 3.1164 & 2.6187 \\ \text { Surface Area, cm }{ }^{2} & 14.1 & 13.5 & - \\ \begin{array}{l}\text { Alpha Intensity, } \\ \alpha /(g-\text { day) }\end{array} & 1.3 \times 10^{15} & 5.2 \times 10^{14} 4.5 \times 10^{14}\end{array}$

Isotopic analysis of the curium and plutonium indicated that $>99.9 \%$ of the alpha activity resulted from ${ }^{244} \mathrm{Cm}$ and ${ }^{238} \mathrm{Pu}$, respectively. ${ }^{244} \mathrm{Cm}$ and ${ }^{238} \mathrm{Pu}$ contents of the final glass buttons were measured calorimetrically to $0.1 \%$. Specific activities and alpha particle energies used for dose rate calculations were taken from the 1 iterature. ${ }^{11}$ The dose rate in the test glasses was 6000 times greater than the calculated initial dose rate in the glass containing actual SRP waste. The test glasses were studied for 420 days. For the glasses containing simulated waste, this corresponded to a alpha dose exceeding $2 \times 10^{17}$ alpha disintegrations per gram of glass. More than $>10^{6}$ years would be required for the glass containing SRP waste to receive this dose (Figure 1).

\section{EFFECT OF ALPHA RADIATION ON ACTINIDE LEACHABILITY}

The effect of alpha radiation on leachability of the actinide elements was examined to determine if the leachability of SRP waste glass would change during long-term storage. The leachabilities for ${ }^{244} \mathrm{Cm}$ and ${ }^{238} \mathrm{Pu}$ in the test glasses containing simulated waste were determined soon after the glasses were made and then 274 to 278 days later (Table 2). No significant differences were observed. The largest dose in the test glasses after 278 days was $3.7 \times 10^{17} \mathrm{\alpha} / \mathrm{g}$. This dose was in the test glass containing ${ }^{244} \mathrm{~cm}$. More than $10^{6}$ years storage would be necessary for SRP waste glass to accumulate this dose (Figure 1). These results indicate that leachability of actinide elements will not significantly change as a result of radiolysis during long-term storage of the waste glass. 
TABLE 2

Leachability of ${ }^{244} \mathrm{Cm}$ or ${ }^{238} \mathrm{Pu}$ from Borosilicate Glasses Containing Simulated Radioactive Wastea

\begin{tabular}{|c|c|c|c|c|}
\hline $\begin{array}{l}\text { Age of } \\
\text { Glass, }\end{array}$ & $\begin{array}{l}\text { Leachability } \\
g / 1 \mathrm{~cm}^{2}-d a y\end{array}$ & & Fraction Leo & 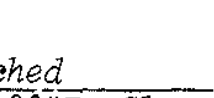 \\
\hline & $244 \mathrm{Cm}$ Glass & ${ }^{3{ }^{8} P u ~ G L a s s}$ & $244 \mathrm{Cm}$ Glass & $2{ }^{3}$ Pu Glass \\
\hline 6 & $0.16 \times 10^{-8}$ & $2.7 \times 10^{-8}$ & $0.14 \times 10^{-8}$ & $3.2 \times 10^{-8}$ \\
\hline 274 & $0.34 \times 10^{-8}$ & $6.2 \times 10^{-8}$ & $0.29 \times 10^{-8}$ & $7.3 \times 10^{-8}$ \\
\hline 275 & $0.98 \times 10^{-8}$ & $5.2 \times 10^{-8}$ & $0.84 \times 10^{-8}$ & $6.1 \times 10^{-8}$ \\
\hline 276 & $0.70 \times 10^{-8}$ & $4.6 \times 10^{-8}$ & $0.60 \times 10^{-8}$ & $5.4 \times 10^{-8}$ \\
\hline 277 & $0.56 \times 10^{-8}$ & $1.6 \times 10^{-8}$ & $0.48 \times 10^{-8}$ & $1.9 \times 10^{-8}$ \\
\hline 278 & $0.21 \times 10^{-8}$ & - & $0.18 \times 10^{-8}$ & - \\
\hline
\end{tabular}

a. Waste was $50 \mathrm{~mol} \%$ each of $\mathrm{Fe}(\mathrm{OH})_{3}$ and $\mathrm{MnO}_{2}$.

b. Samples were 1 eached in $150 \mathrm{~mL}$ of distilled water at ambient temperature for 24 hours. Fresh water was added daily.

Another result evident in Table 2 is that the leachability did not significantly change with leach time. Over a 4-day leach period, the fractions of activity leached were $2 \times 10^{-8}$ for ${ }^{244} \mathrm{Cm}$ and $2 \times 10^{-7}$ for ${ }^{2{ }^{38}} \mathrm{Pu}$. The consistently higher values for ${ }^{238} \mathrm{Pu}$ suggest that this isotope is not held in the matrix as strongly as is $244 \mathrm{Cm}$.

Other workers ${ }^{8}, 9$ have also found no affect of alpha dose on leachability. Also, the values in Table 2 agree with those determined for leachability of alpha activity from test samples of glass containing actual radioactive SRP waste. ${ }^{2}$

Leachabilities were measured in $150 \mathrm{~mL}$ of stirred, distilled water at $25^{\circ} \mathrm{C}$. Leach water was changed daily. Leachabilities, $\mathrm{L}$, were calculated from

$$
L=f(M / A)(1 / t)
$$

where

$$
f=\text { the fraction of }{ }^{244} \mathrm{Cm} \text { or }{ }^{238} \mathrm{Pu} \text { leached during time } t
$$

$\mathrm{M} / \mathrm{A}=$ the mass-to-surface area ratio of the sample

The amount of isotope leached was based on measurements of alpha activity of leach water. 


\section{EFFECT OF ALPHA RADIATION ON GLASS VOLUME}

Because other studies ${ }^{12,13}$ had shown that radiation can cause glasses to contract or expand, the effect of internal alpha radiation on the density of the tests glasses was examined. Results indicated that the glasses expanded with increasing alpha dose (Figure 2). For glass containing SRP waste, the dose after $10^{6}$ years storage will be $8 \times 10^{16} \mathrm{\alpha} / \mathrm{g}$ of glass (Figure 1). At this dose, Figure 2 indicates a fractional expansion of $<0.1 \%$. Over the time period of $10^{6}$ years storage, this fractional expansion is insignificant.

Other studies 12,13 have shown that vitreous silica and also borosilicate glasses containing only small quantities of glass network modifiers such as $\mathrm{Na}_{2} \mathrm{O}$ or $\mathrm{K}_{2} \mathrm{O}$ exhibit negative dilatations when externally irradiated. This contraction has been explained by radiolytic displacement of bonded oxygen into the free volume of the glass network. ${ }^{13}$

In glasses containing simulated waste, the free volume is filled with network modifiers such as $\mathrm{MnO}_{2}$ or $\mathrm{Fe}_{2} \mathrm{O}_{3}$. In this case, bond breakage leads to network expansion or positive dilitation. Such expansion has also been observed in vitreous silica containing aluminum as an impurity when the glass is

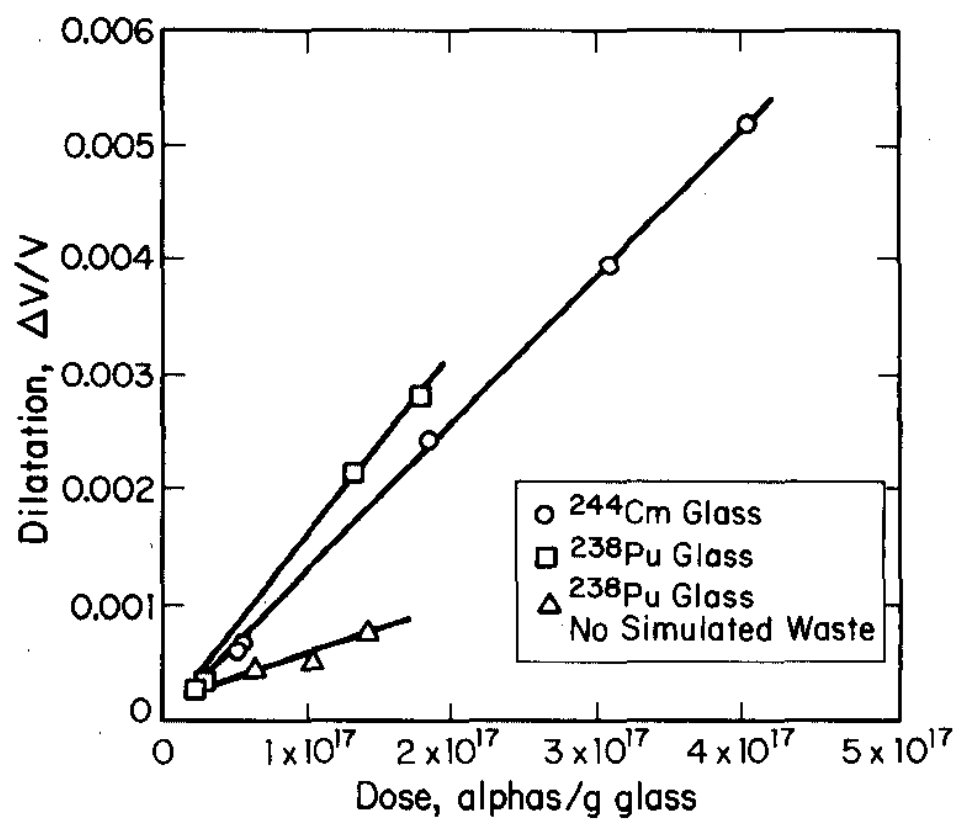

FIGURE 2. Positive Dilation due to Internal Alpha Radiolysis of Borosilicate Glasses Containing ${ }^{244} \mathrm{Cm}$ or ${ }^{238} \mathrm{Pu}$ 
irradiated externally with X-rays, gamma rays, or electrons. ${ }^{14}$ The hypothesis that expansion results when the network free volume is filled with waste is supported by a lower rate of expansion for glass containing ${ }^{238} \mathrm{Pu}$ but no simulated waste (Figure 2). This glass still expanded, because of the effect of the relatively large amounts of sodium, calcium, and titanium in the glass. However, expansion is not so fast because the free volume in the network is higher than with the other two test glasses containing simulated waste. For the three glasses, expansion rates in volume percent/Grad are 0.017 for the ${ }^{238} \mathrm{Pu}$ glass with waste, 0.012 for the ${ }^{244} \mathrm{Cm}$ glass with waste, and only 0.0043 for the ${ }^{238} \mathrm{Pu}$ glass with no waste. In other studies, ${ }^{8}$ internal alpha radiolysis caused a lead borosilicate glass to expand and a zinc borosilicate glass to contract. Glass composition appears to govern whether the glass expands or contracts.

Glass densities were determined at $22 \pm 1^{\circ} \mathrm{C}$ by weighing samples in air and in carbon tetrachloride. Each determination included a density measurement of a silicon standard. Reproducibility of standards indicated that errors caused by experimental technique were negligible.

\section{EFFECT OF ALPHA RADIATION ON GLASS MICROSTRUCTURE}

To determine the effects of internal alpha radiation on glass microstructure, the three test glasses were fractured, and fresh surfaces were examined by electron microscopy. A glass of composition identical to that containing the simulated waste but not containing ${ }^{244} \mathrm{Cm}$ or ${ }^{238} \mathrm{Pu}$ was also fractured and examined. Typical results are shown in Figure 3. All three radioactive glasses exhibited randomly oriented mircocracks that were not present in the nonradioactive glass. These microcracks may result from stresses produced by radiolytic bond breakage, and may account for the observed positive dilatation. Current data are insufficient to establish whether the cracks are due to alpha radiolysis or helium accumulation. These microcracks did not appear to increase significantly the leachabilities of ${ }^{244} \mathrm{Cm}$ or ${ }^{23} \mathrm{Pu}$ (Table 2).

Another effect of alpha decay on glass microstructure observed on1y in the radioactive glasses was the blistering of portions of the glass surfaces after 20 to 30 seconds of exposure to the electron beam in an electron microscope. The blistering is shown in Figure 4 where a square of blisters, formed at a magnification of $2000 \mathrm{x}$, appears in the middle of an image photographed at 500X. The microcracks are also evident in this figure. Al1 attempts to form these blisters on nonradioactive glass containing simulated waste failed. In the two radioactive glasses, 

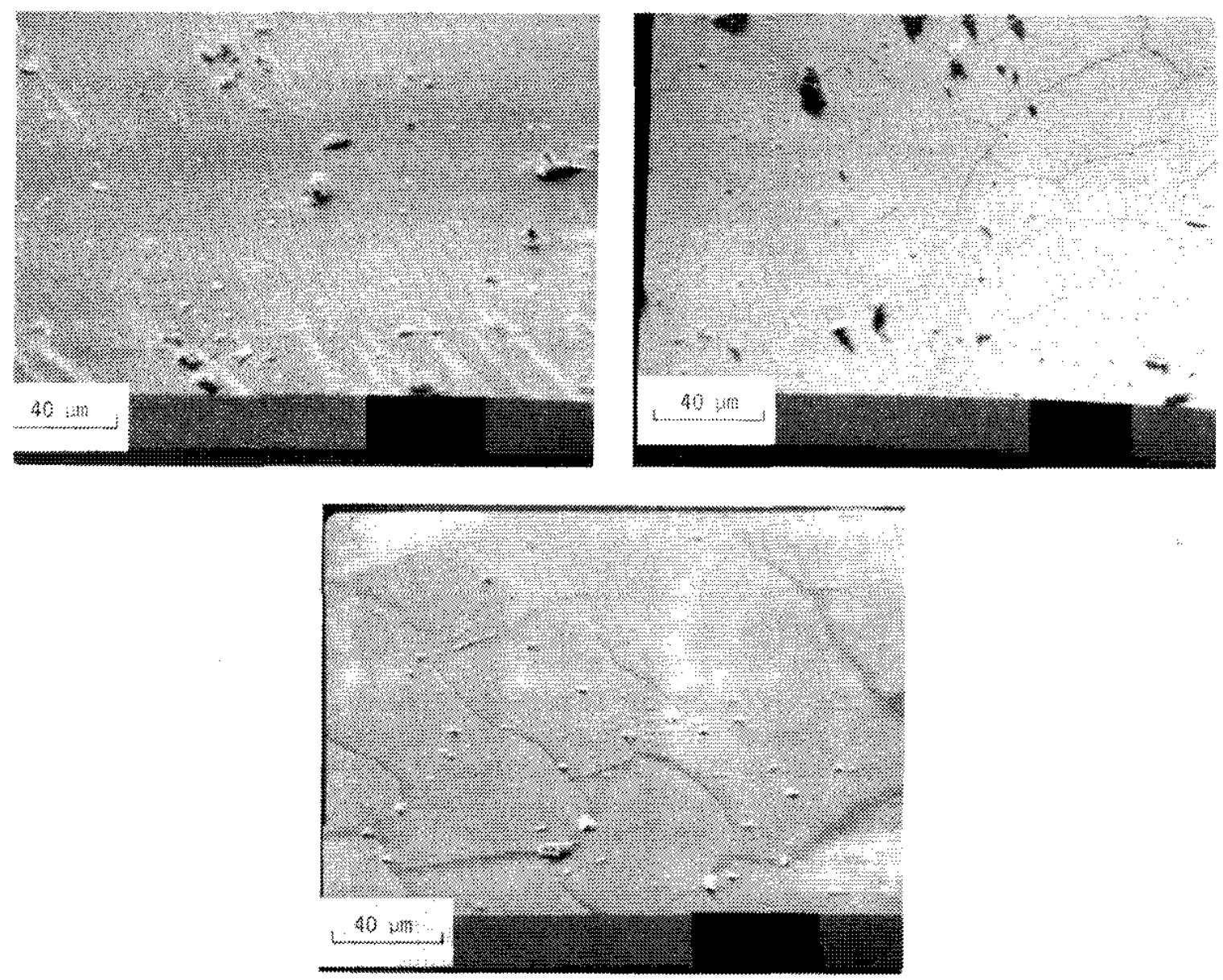

FIGURE 3. Electron Microscope Images of Borosilicate Glasses Containing Simulated Radioactive Wastes 


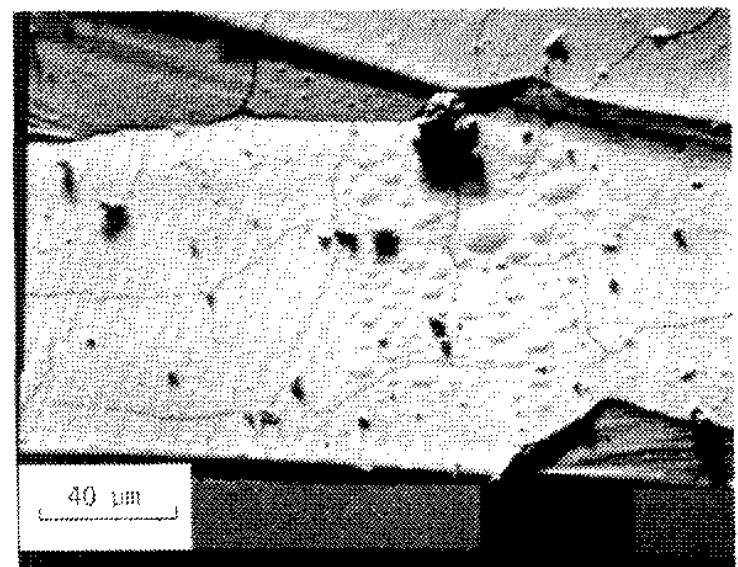

FlGuRE 4. Blister Formation on a Borosilicate Glass Containing 238 pu Due to Exposure to a Beam in an Electron Microscope

agglomexation of helium initiated by electron beam-heating of the surface could account for blister formation. Formation of bubbles and microcracks by dissolved gases in glasses has been reported previously. ${ }^{15}$ Heating of a sillcate glass containing w mol argon to $245^{\circ} \mathrm{C}$ caused bubble formation; when a similar glass containing 1 mol o helinm was heated to $560^{\circ} \mathrm{C}$, microm cracks formed.

\section{HELIUM ACCUMULTION IN THE GLASS}

In glass containing alpha emitters, helium will be generated internally by neutralization of the alpha particles. This helum must erther diffuse from the glass or be accommodated whin the glass, either interstitially or in voids in the glass. The hypothesis that this helium accumiation might cause the glass to crack ox break was tested. Test glasses were observed after they had accumulated helium concentrations at least twice that calculated for SRP waste glass after $10^{6}$ years storage. No macrostmotural damage was evident. Only the microcracks discussed previously had formed, and these did not affect the leachability of the glass.

Whe waste glass stored for $10^{6}$ years will have accumlated $0.006 \mathrm{~cm}^{3}$ He(STP)/ $\mathrm{cm}^{3}$ glass. The helium concentrations in the test glasses of the same units stored for 420 days were 0.061 for the ${ }^{24+4} \mathrm{Cm}$ glass, 0.025 for the ${ }^{238} \mathrm{pu}$ glass with simulated wate, and 0.018 for the ${ }^{238} \mathrm{pu}$ glass without simulated waste. These concentrations were calculated by assuming no diffusion of he from the glasses. Published data ${ }^{3}$ in indicate that no diffusion from the glass would occur at room temperature. 
In another study, ${ }^{9}$ a test glass had accumulated $0.071 \mathrm{~cm}^{3}$ $\mathrm{He}$ (STP) $/ \mathrm{cm}^{3}$ glass, or $\sim 12$ times higher than the concentration in the SRP waste glass after $10^{6}$ years. No visible damage was reported for this test glass. The same study a1so confirmed that helium had not diffused from the glass.

\section{STORED ENERGY RESULTING FROM ALPHA RADIATION}

Internal alpha radiolysis of glass containing SRP waste will produce stored energy in the glass. The main concern with stored energy is that it will be released by some mechanism and cause a rapid temperature rise in the glass. This temperature excursion could cause damage to the glass or its container or cause volatilization of radioactive material. Although stored energy was not studied for glass with SRP waste, results of published studies ${ }^{8}, 10$ are applicable. The maximum amount of stored energy observed has been $\sim 35 \mathrm{cal} / \mathrm{g}$ of glass at doses in excess of $2 \times 10^{16} \mathrm{\alpha} / \mathrm{g}$ of glass. ${ }^{8}$ These data $^{9}$ indicate that a $6 \times 10^{16} \mathrm{\alpha} / \mathrm{g}$, the maximum dose that will occur with glass containing SRP waste, the amount will be less than $6 \mathrm{cal} / \mathrm{g}$. Calculations ${ }^{20}$ indicate that this amount of stored energy cannot cause a temperature excursion in excess of $\sim 50^{\circ} \mathrm{C}$. This is not sufficient to cause damage to the glass or its container or cause volatilization of radioactive material. 


\section{REFERENCES}

1. J. A. Kelley. Evaluation of Glass as a Matrix for Solidification of Savannah River Plant Waste. USERDA Report DP-1382, Savannah River Laboratory, E. I. du Pont de Nemours and Company, Aiken, S. C. (1975).

2. J. A. Kelley. Evaliation of Glass as a Waste Solidification Matrix - Radioactive Studies. USERDA Report DP-1397, Savannah River Laboratory, E. I. du Pont de Nemours and Company, Aiken, S. C. (1975).

3. R. M. Wallace, H. L. Hul1, and R. F. Bradley. Solid Forms for Savannah River Plant High-Level Waste. USERDA Report DP-1335, Savannah River Laboratory, E. I. du Pont de Nemours and Company, Aiken, S. C. (1973).

4. J. R. Grover. "Glasses for Fixation of High Level Radioactive Wastes" in Symposium on Management of Wastes from Fuel Reprocessing, p 593, IAEA, Paris (1972).

5. R. Bonniaud. "La Vitrification en France des Solutions de Produits de Fission" Nucl. Technol., 34, 449 (1977).

6. J. L. McElroy, A. G. Blasewitz, and K. J. Schneider. "Status of the Waste Solidification Program" Nucl. Technol., $12,69(1971)$.

7. W. W. Schulz, A. L. Dressen, C. W. Hobbick, and H. Babad. Glass Forms for Immobilization of Hanford Wastes. USERDA Report ARH-SA-210, Atlantic Richfield Hanford Co., Richland, Washington (1975).

8. J. E. Mendel, W. A. Ross, F. P. Roberts, R. P. Turcotte, Y. B. Katayama, and J. H. Westsik, Jr., "Thermal and Radiation Effects on Borosilicate Waste Glasses" in International Symposium Management of Radioactive Wastes from the Nuclear Fuel Cycle, Vo1. 2 IAEA-SM-207/100, Vienna (1976).

9. A. R. Hall, J. T. Dalton, B. Hudson, and J. A. C. Marples. "Development of Radiation Stability of Glasses for Highly Radioactive Wastes from the Nuclear Fuel Cycle," Vol. 2, IAEA-SM-207/24, Vienna (1976). 
10. J. E. Mende1, W. A. Ross, F. P. Roberts, R. P. Turcotte, Y. B. Katayama, and J. H. Westsik, Jr. Thermal and Radiation Effects on Borosilicate Waste Glasses. USERDA Report BNWL-1893, Battelle-Pacific Northwest Laboratory, (1975) .

11. Y. A. Ellis and A. H. Wapstra. Nuclear Data Sheets, Vo1. 3, No. 2, Academic Press, New York (1969).

12. C. Mylonas and R. Truel1. "Radiation Effects from $(n, \alpha)$ Reactions in Boron Glass and Energy of the Reacting Neutrons." J. Appl. Phys. 29, 1252 (1958).

13. W. Primak and R. Kampwirth. "The Radiation Compaction of Vitreous Silica." J. Appl. Phys., 39, 5651 (1968).

14. W. Primak and R. Kampwirth. "Impurity Effect in the Ionization of Vitreous Silica." J. Appl. Phys., 39, 6010 (1968).

15. S. P. Faile and D. M. Roy. "Solubilities of $\mathrm{Ar}, \mathrm{N}_{2}, \mathrm{CO}_{2}$, and He in Glasses at Pressures to 10 Kbards." J. Am. Ceram. Soc., 49, 638 (1966).

16. R. P. Turcotte. Radiation Effects in Solidified High-Level Waste, Part 2 - Helium Behavior. USERDA Report BNWL-2051, Battelle-Pacific Northwest Laboratory, Richland, Washington, (1976) . 